\title{
A meiofauna e os Nematoda da enseada Martel (Antártica) e seu uso em monitoramento ambiental.
}

\section{Dissertação: Paula Foltran Gheller}

\section{RESUMO:}

O objetivo deste estudo foi avaliar se a estrutura da comunidade da meiofauna, das famílias e dos gêneros de Nematoda apresentam alterações devido à atividade antrópica na área próxima a Estação Antártica Brasileira (CF), em comparação com um controle (BP). A densidade média (ind.10 $\left.\mathrm{cm}^{-2}\right)$ da meiofauna total variou entre 7028 ( \pm 1529$)$ e $16245( \pm 12282)$ nos 20-30 m e entre 1569 ( \pm 928$)$ e 7088 ( \pm 10338$)$ nos 50-60 m, corroborando os valores altos já descritos para a zona rasa antártica. Nematoda foi dominante (>90\%), seguido de Nauplii e Copepoda. 65 gêneros e 3 subfamílias de Nematoda foram encontrados, pertencentes a 24 famílias. Daptonema, Halailamus, Dichromadora, Sabatieria, Aponema e Sphaerolaimus foram dominantes nas duas profundidades, mas tiveram densidades mais altas nos 20-30 m relacionadas à maior biomassa de clorofila $a$. Não foram identificadas alterações na estrutura da comunidade da meiofauna, das famílias ou gêneros de Nematoda que pudessem ter sido causados por impacto antrópico. Porém, a riqueza e a diversidade das famílias e dos gêneros de Nematoda foram menores em CF, o que sugere um possível impacto, sendo importante a continuidade do monitoramento e a inclusão de outras áreas de referência. O nível taxonômico de família foi o mais apropriado para um estudo de monitoramento da zona costeira rasa antártica, visando o melhor custo-benefício.

Descritores: meiofauna, Antártica, zona costeira, Nematoda, monitoramento ambiental. 


\title{
Meiofauna and nematodes from Martel inlet (Antarctica) and their use in environmental monitoring.
}

\section{Dissertation: Paula Foltran Gheller}

\begin{abstract}
:
The aim of this study was to verify if meiofauna, Nematoda family and genera community structure show modification caused by human activities at the Brazilian Antarctic Station (CF), in relation to a reference area (BP). Mean meiofauna densities (ind.10 $\left.\mathrm{cm}^{-2}\right)$ ranged from $7028( \pm$ $1529)$ to $16245( \pm 12282)$ at 20-30 $\mathrm{m}$ and from $1569( \pm 928)$ and $7088( \pm 10338)$ at 50-60 m, being high as already described for the Antarctic coastal zone. Higher densities at 20-30m were correlated to more chlorophyll $a$ and sand. Nematoda were dominant (>90\%) followed by Nauplii and Copepoda. 65 genera and 3 subfamilies of Nematoda were found, belonging to 24 families. Daptonema, Halailamus, Dichromadora, Sabatieria, Aponema and Sphaerolaimus were dominant at both depths, but had higher densities at 20-30 m, which were correlated to higher chlorophyll a biomasses. Analysis for all levels of taxonomic resolution, separated the samples between depths, but not between areas, so differences caused by human impact were not detected. Number of genera ranged from 12 to 34 and diversity from 1.57 to 4.22 bits/ind, both being higher at 50-60m at BP, suggesting that an impact might have occurred, so monitoring should continue and be extended to other control areas. Identification of Nematoda to family level would be enough to evaluate environmental impact of the coastal antarctic zone.
\end{abstract}

KEY WORDS: meiofauna, Antarctica, coastal zone, Nematoda, environmental impact, monitoring. 